\title{
FABRIC DRAPING AND COTTON FABRIC STRUCTURE RELATION ANALYSIS
}

Tatjana Šarac ${ }^{1^{*}}$, Jovan Stepanović ${ }^{1}$, Goran Demboski², Vasilije Petrović ${ }^{3}$

(ORIGINAL SCIENTIFIC PAPER)

UDC 684.75

${ }^{1}$ Faculty of Technology, Leskovac, University of Niš, Serbia

2 Faculty of Technology and Metallurgy, Skopje, University of Skoplje, Republic of Macedonia

${ }^{3}$ Technical faculty, Zrenjanin, University of Novi Sad, Serbia

Draping can be defined as a phenomenon of crease-forming when the fabric is put under pressure of its own mass, but without the influence of external forces. The drape ability of the material has a direct influence on the appearance and functionality of the garment. Recent findings in this field indicate that researchers have mostly been defining the phenomenon of draping on the basis of the mechanical characteristics of textiles. This paper presents the method that aims to predict the draping parameters, where drape is defined in dependence of the structure and construction parameters of the woven fabric. A particular attention is focused on connecting the drape coefficient with the fabric weight and relative density of the fabric. Relative density is defined by the structure and construction parameters of the fabric such as: yarn count (tex), fiber density $(\mathrm{g} \cdot \mathrm{cm}-3)$, the coefficient (factor) of fiber packing in the yarn, the weave repeat, the number of effect-changes in the repeat, the position of intersection points in the weave repeat and the flexibility coefficient of yarns.
Keywords: draping, relative density, fabric, cotton

\section{Introduction}

Draping is an important factor in presenting the aesthetics and functionality of the woven fabric as well as sewn garments. Generally speaking, draping can be defined as a phenomenon of crease-forming when the fabric is put under pressure of its own mass, but without the influence of external forces. Draping of the fabric depends on mechanical and structural characteristics of the fabric, as well as on various external influences from the environment [1].

The ability of a material to become draped is a feature that defines the qualitative characteristics of fabrics as well as the design of clothing products. Modern fashion trends and modern technologies impose more requirements to textile industry. New and functional textile materials, modern methods of making clothes, the competition in the fashion and clothing industry are factors that impose constant changes and adjustments to the market on the textile industry.

As a numerical indicator of a drape ability of fabrics a drape coefficient (DC) is used, which can be defined as a ratio of a ring area of the fabric sample before draping and a projected area of the draped part of the fabric (Figure 1). In addition to the drape coefficient, maximum (Amax) and minimum amplitude (Amin) are used for describing the ability of the fabric drape, which represents maximum and minimum distance from the center of the circle to the edge of the draped part of the fabric sample (Figure 1), and the number of folds ( $n$ ) [2].

Extensive studies of the fabric drape have led to some conclusions. The greatest impact on the drape coefficient has fabric stiffness [3]. It was also revealed that the drape coefficient depends, besides on mechanical, on structural characteristics of the fabric such as: structure, type of yarn, raw material composition, applied weave repetition, fabric density etc. [4].

Draping can be classified into two categories: as twodimensional and three-dimensional draping. Two-dimensional draping means that the fabric folds under the influence of gravity in one plane, and three-dimensional draping means that fabric deforms forming the folds in more than one plane under the pressure of its own mass [5].

A number of researchers involved in the analysis of the phenomenon of the fabric drape. Pierce's cantilever method and Cusick's drape meter for measuring the fabric drape parameters are well-known. Current studies of the fabric drape are going in several directions, and researchers agree that draping is a very complex phenomenon and depends on many parameters [1].

*Author address: Tatjana Šarac, Faculty of Technology, University of Niš, Bulevar oslobodjenja 124, 16000 Leskovac, Serbia

E-mail: tangerine_art@hotmail.com

The manuscript received: March, 30, 2015.

Paper accepted: April, 23, 2015. 


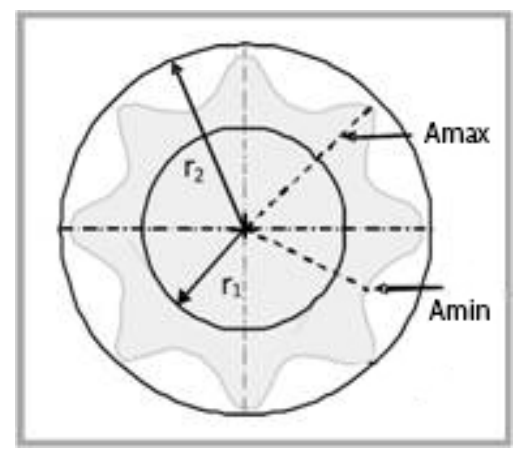

Figure 1. Projection of the draped sample of the fabric

\section{Experimental}

For the purpose of this research, 31 fabrics of the same fiber composition - $100 \%$ cotton were taken. For each analyzed fabric following parameters were determined: weave repeat, fabric weight $(Q)$, density of the warp threads in the fabric (dwa), density of the warp threads in the fabric (dwe), warp yarn count (Tt,wa), weft yarn count $(T t, w e)$ and yarn twist (number of twist/ meter) (table 1).
The determination of drape parameters was performed on a standard drape tester model 665 producer James $\mathrm{H}$ Heal \& Co of England, according to British Standard BS 5058.

For all the samples the drape coefficient (DC), the maximum (Amax) and the minimum amplitude (Amin) and the number of folds ( $n$ ) were determined.

This experimental method means that a circular fabric sample $30 \mathrm{~cm}$ in diameter hangs on a circular disk $18 \mathrm{~cm}$ in diameter. The sample with the diameter of $36 \mathrm{~cm}$ can be used for rigid fabrics if their DC\% s greater than $85 \%$ in the fabric sample with a diameter of $30 \mathrm{~cm}$, while in the case of the soft fabric $24 \mathrm{~cm}$ diameter sample can be used if their DC\% in the $30 \mathrm{~cm}$ diameter fabric sample is less than $30 \%$ [6].

However, if a different diameter of the fabric samples would be used for this study, the obtained results of the drape coefficient could not be in correlation with other parameters of the fabrics because the increase of the draped part of the sample reduces the drape coefficient, so all the fabric samples were tested with a diameter of $30 \mathrm{~cm}$ regardless of the results of the drape coefficient which were less than $30 \%$ or greater than $80 \%$.

Table 1. Characteristics of the tested fabrics

\begin{tabular}{|c|c|c|c|c|c|c|c|c|}
\hline \multirow{2}{*}{$\frac{\frac{0}{0}}{\frac{2}{5}}$} & \multirow{2}{*}{$\begin{array}{l}\text { Weave } \\
\text { repeat }\end{array}$} & \multirow{2}{*}{$\begin{array}{c}\text { Fabric weight } \\
Q \\
\text { (declared) } \\
\left(\mathbf{g} / \mathbf{m}^{2}\right)\end{array}$} & \multicolumn{2}{|c|}{$\begin{array}{c}\text { Yarn (threads) } \\
\text { density } \\
\left(\mathrm{cm}^{-1}\right)\end{array}$} & \multicolumn{2}{|c|}{$\begin{array}{l}\text { Yarn count } \\
\text { (tex) }\end{array}$} & \multicolumn{2}{|c|}{$\begin{array}{c}\text { Yarn twist } \\
\text { (No of twist } / \mathrm{m} \text { ) }\end{array}$} \\
\hline & & & $\begin{array}{c}\text { Warp } \\
d_{\text {wa }}\end{array}$ & $\begin{array}{l}\text { Weft } \\
d_{w e}\end{array}$ & $\begin{array}{c}\text { Warp } \\
T_{t, \text { wa }}\end{array}$ & $\begin{array}{c}\text { Weft } \\
T_{t, \text { we }}\end{array}$ & Warp & Weft \\
\hline 1 & Plain & 143 & 27 & 18 & 30 & 30 & 846 & 846 \\
\hline 2 & Plain & 220 & 22 & 22 & 50 & 48 & 586 & 586 \\
\hline 3 & Plain & 150 & 40 & 25 & 20 & 25 & 826 & 748 \\
\hline 4 & Plain & 200 & 30 & 22 & 30 & 34 & 846 & 590 \\
\hline 5 & Plain & 155 & 28 & 22 & 30 & 30 & 708 & 708 \\
\hline 6 & Plain & 315 & 16 & 15 & $64 \times 2$ & 64 & 330 & 570 \\
\hline 7 & Plain & 150 & 24 & 24 & 30 & 30 & 842 & 842 \\
\hline 8 & Plain & 200 & 37 & 20 & $17 \times 2$ & $17 \times 2$ & 680 & 680 \\
\hline 9 & Plain & 117 & 43 & 28 & $7.6 \times 2$ & 17 & 1000 & 866 \\
\hline 10 & Plain & 70 & 26 & 23 & $6 \times 2$ & $6 \times 2$ & 1200 & 1200 \\
\hline 11 & Plain & 77,67 & 50 & 34 & 8,4 & 8,4 & 1048 & 1178 \\
\hline 12 & Plain & 132,8 & 47 & 29 & 15 & 16 & 790 & 795 \\
\hline 13 & Twill 2/1 & 216,28 & 49 & 26 & 24 & 28 & 580 & 576 \\
\hline 14 & Twill 2/1 & 172 & 43 & 25 & 25 & 25 & 748 & 748 \\
\hline 15 & Twill 2/1 & 200 & 40 & 27 & 30 & 30 & 708 & 708 \\
\hline 16 & Twill 2/1 & 157 & 56 & 27 & 17 & 20 & 866 & 826 \\
\hline 17 & Twill 3/1 & 312 & 48 & 21 & 30 & 72 & 846 & 551 \\
\hline 18 & Twill 3/1 & 221 & 48 & 23 & 30 & 30 & 708 & 708 \\
\hline 19 & Twill 3/1 & 275 & 49 & 24 & 30 & 42 & 708 & 472 \\
\hline 20 & Twill 3/1 & 185 & 22 & 22 & 38 & 38 & 630 & 630 \\
\hline 21 & Twill 3/1 & 260 & 42 & 19 & 33 & 50 & 768 & 590 \\
\hline 22 & Twill 3/1 & 248 & 44 & 21 & 30 & 50 & 708 & 532 \\
\hline 23 & Twill 3/1 & 270 & 48 & 22 & 28 & 28 & 700 & 580 \\
\hline 24 & Twill 2/2 & 275 & 27 & 16 & $30 \times 2$ & 64 & 500 & 566 \\
\hline 25 & Twill 2/2 S & 182,20 & 21 & 19 & $20 \times 2$ & $19 \times 2$ & 578 & 568 \\
\hline 26 & Twill 4/4 Z & 302,21 & 27 & 19 & $30 \times 2$ & $30 \times 2$ & 366 & 373 \\
\hline 27 & Panama $2 / 2$ & 196 & 37 & 22 & $17 \times 2$ & $17 \times 2$ & 680 & 680 \\
\hline 28 & Panama 2/2 & 324 & 43 & 23 & 34 & 72 & 708 & 394 \\
\hline 29 & Satin & 330 & 44 & 22 & 34 & $34 \times 2$ & 708 & 500 \\
\hline 30 & Satin & 185 & 46 & 25 & $10 \times 2$ & $17 \times 2$ & 820 & 820 \\
\hline 31 & Satin & 165 & 39 & 28 & 25 & 25 & 748 & 748 \\
\hline
\end{tabular}


Then the parameters that define the relative density of the threads in the fabric (the fiber density $\left(\mathrm{g} \cdot \mathrm{cm}^{-3}\right)$ were calculated, the coefficient (factor) of fiber packing in the yarn, the weave repeat, the number of effect-changes in the repeat, the position of intersection points in the weave repeat and the flexibility coefficient of yarns) [7].

Relative densities of warp and weft threads (Table 2) were determined using the equation $[7,8]$ :

$d_{r e l, w a}=\frac{d_{w a}}{280,25}\left[\frac{a_{w e}\left(2,6-0,6 z_{w e}\right)}{f_{w e} R_{w a}}\left(\sqrt{v_{w a}^{2}+2 v_{w a} v_{w e}}-v_{w a}\right)+v_{w a}\right]$

$d_{\text {rel }, w e}=\frac{d_{w e}}{280,25}\left[\frac{a_{w a}\left(2,6-0,6 z_{w a}\right)}{f_{w a} R_{w e}}\left(\sqrt{v_{w e}{ }^{2}+2 v_{w a} v_{w e}}-v_{w e}\right)+v_{w e}\right] \ldots$.

$v_{w a}=\sqrt{\frac{T_{t, w a}}{\rho_{w a} \cdot p_{w a}}} \quad v_{w e}=\sqrt{\frac{T_{t, w e}}{\rho_{w e} \cdot p_{w e}}}$.

A relative density of the fabric (Table 2 ) is determined by using the following equation:

$d_{r e l}=\sqrt{d_{r e l, w a} \cdot d_{r e l, w e}}$
Where are:

$T_{t, w a}, T_{t, w e}-$ warp and weft yarn count (tex),

$d_{\text {wa }}, d_{\text {we }}-$ the density of warp and weft wires in fabric $\left(\mathrm{cm}^{-1}\right)$,

$R_{w a}, R_{w e}$ - weave repeat in the appropriate direction

awa, awe - the number of effect-changes in the repeat

pwa, pwe - fiber density $\left(\mathrm{g} \cdot \mathrm{cm}^{-3}\right)$

pwa, pwe - the coefficient (factor) of fiber packing

Zwa, Zwe - the position of intersection points in the weave repeat

$f_{w a}, f_{w e}-$ the flexibility coefficient of yarns

Uwa, Uwe - the volume's coefficient of yarns

drel,wa - relative density of warp threads

drel,we - relative density of weft threads

drel - relative density of fabric

\section{Results and discussion}

The obtained results are shown in Table 2. Based on the research results (Tables 1 and 2) corresponding correlations are shown in Figures 2, 3 and 4.

Table 2. Obtained results

\begin{tabular}{|c|c|c|c|c|c|c|}
\hline 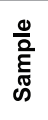 & Weave repeat & $\begin{array}{c}\text { Fabric weight } \\
Q \\
\text { (measured) } \\
\left(\mathbf{g} / \mathbf{m}^{2}\right)\end{array}$ & $\begin{array}{c}\text { Relative } \\
\text { density of } \\
\text { warp threads } \\
d_{r e l, w a}\end{array}$ & $\begin{array}{c}\text { Relative } \\
\text { density of weft } \\
\text { threads } d_{r e l, w e}\end{array}$ & $\begin{array}{c}\text { Relative } \\
\text { density of } \\
\text { fabric } \\
d_{r e l}\end{array}$ & $\begin{array}{l}\text { Drape } \\
\text { coefficient } \\
\text { DC (\%) }\end{array}$ \\
\hline 1 & Plain & 154,32 & 0.867767 & 0.578511 & 0.708529 & 68,7 \\
\hline 2 & Plain & 232 & 0.906276 & 0.900882 & 0.903575 & 87,5 \\
\hline 3 & Plain & 156,5 & 1.092672 & 0.705588 & 0.878052 & 68,7 \\
\hline 4 & Plain & 191,44 & 0.985981 & 0.736412 & 0.852108 & 73,3 \\
\hline 5 & Plain & 163,88 & 0.899907 & 0.707069 & 0.797682 & 79,2 \\
\hline 6 & Plain & 311,52 & 0.946165 & 0.801038 & 0.870583 & 85,8 \\
\hline 7 & Plain & 170,43 & 0.771348 & 0.771348 & 0.771348 & 72 \\
\hline 8 & Plain & 208,31 & 1.26596 & 0.684303 & 0.930752 & 75,6 \\
\hline 9 & Plain & 126,16 & 1.003555 & 0.664263 & 0.81647 & 57,2 \\
\hline 10 & Plain & 67,08 & 0.528497 & 0.467517 & 0.497073 & 30 \\
\hline 11 & Plain & 77,67 & 0.850332 & 0.578226 & 0.701202 & 58,1 \\
\hline 12 & Plain & 132,8 & 1.08045 & 0.672983 & 0.852716 & 56 \\
\hline 13 & Twill 2/1 & 216,28 & 1.224243 & 0.672288 & 0.907218 & 80,4 \\
\hline 14 & Twill 2/1 & 184,63 & 1.07296 & 0.623814 & 0.818124 & 73,7 \\
\hline 15 & Twill 2/1 & 220,73 & 1.093367 & 0.738022 & 0.898292 & 74,7 \\
\hline 16 & Twill 2/1 & 156,5 & 1.178956 & 0.589377 & 0.833577 & 63,9 \\
\hline 17 & Twill 3/1 & 325,36 & 1.334905 & 0.741122 & 0.994649 & 80,3 \\
\hline 18 & Twill 3/1 & 224,71 & 1.196711 & 0.573424 & 0.828386 & 82 \\
\hline 19 & Twill 3/1 & 276,08 & 1.271209 & 0.682306 & 0.931318 & 87,6 \\
\hline 20 & Twill 3/1 & 185,48 & 0.617308 & 0.617308 & 0.617308 & 79 \\
\hline 21 & Twill 3/1 & 255,1 & 1.153987 & 0.58451 & 0.821289 & 77,6 \\
\hline 22 & Twill 3/1 & 269,41 & 1.166548 & 0.639762 & 0.863894 & 82 \\
\hline 23 & Twill 3/1 & 204,62 & 1.156133 & 0.529894 & 0.782706 & 72,9 \\
\hline 24 & Twill 2/2 & 294,94 & 0.959058 & 0.578395 & 0.744792 & 85,6 \\
\hline 25 & Twill 2/2 S & 175,64 & 0.601051 & 0.536274 & 0.56774 & 48,6 \\
\hline 26 & Twill 4/4 Z & 302,21 & 0.814363 & 0.6457 & 0.725144 & 60 \\
\hline 27 & Panama $2 / 2$ & 208,69 & 0.960964 & 0.571384 & 0.740999 & 70,2 \\
\hline 28 & Panama $2 / 2$ & 312,54 & 1.225046 & 0.803656 & 0.992228 & 86,5 \\
\hline 29 & Satin & 330,57 & 1.077277 & 0.688174 & 0.861019 & 72,9 \\
\hline 30 & Satin & 196,17 & 0.851934 & 0.558554 & 0.689819 & 66,2 \\
\hline 31 & Satin & 183,76 & 0.774697 & 0.556193 & 0.656415 & 63,4 \\
\hline
\end{tabular}


Figure 2 shows the dependence of the drape coefficient and the product of number of folds and the quotient of the maximum and minimum amplitude. The results indicate that there is a correlation of these parameters analyzed.

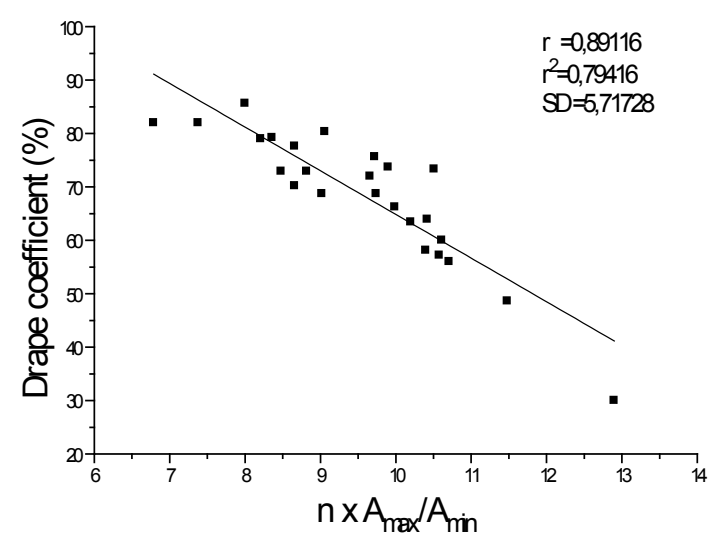

Figure 2. Dependance of drape coefficient and $n \times A m a / A m i n$

The dependence of the drape coefficient, the number of folds and the maximum and minimum amplitude (Fig. 2) can be represented by the regression equation:

$$
D C=146,6-8,2 \cdot n \cdot \frac{A_{\max }}{A_{\min }}[\%] .
$$

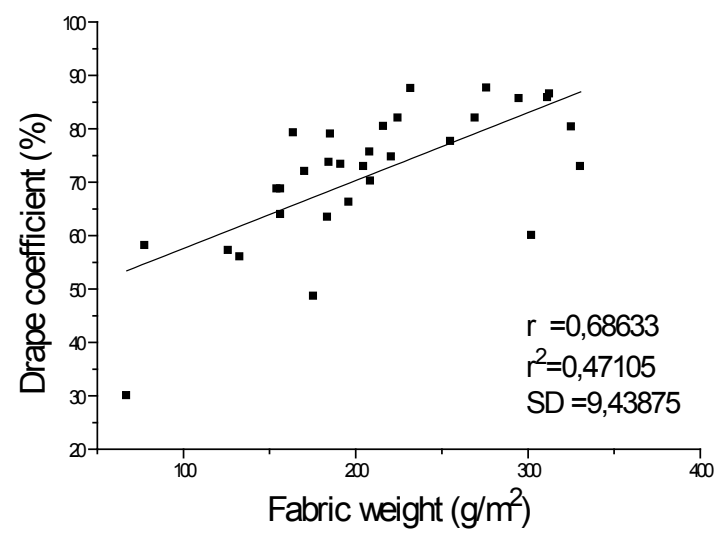

Figure 3. Dependance of drape coefficient and fabric weight

The dependence of the drape coefficient and the fabric weight (Fig. 3) can be represented by the regression equation:

$$
D C=44,9+0,127 \cdot m_{m^{2}}[\%]
$$

Figure 3 shows the dependance of the drape coefficient and the fabric weight. The results show that the fabrics with a higher fabric weight have a higher drape coefficient. The fabric weight has a direct impact on the drape coefficient because the fabric drape represents a folding of fabric under the influence of gravity and folding depends on the mass of the draped part of the fabric.

A prominent place in the process of projecting of elements of structure and construction of the cotton fabric takes the relative density of the two-yarn system [7]. When projecting a relative density of yarns in fabrics, special attention must be paid to: fibers characteristics (the surface structure and shape of the cross section, length, crimp, fiber volume mass), yarn characteristics (the applied process of spinning and twisting, yarn count and yarn volume mass), characteristics of the weaving process (the process of preparing warp for weaving, the absolute yarn density in fabrics, construction, tightness of warp and weft systems etc.). Since the relative density includes a number of parameters of woven fabrics, the attempt is made to connect the drape coefficient with characteristics that define the relative density and to create the conditions for the proper prediction of the woven fabrics drape for clothing industry.

Figure 4 shows the correlation of relative density of the fabric with the drape coefficient. The results indicate that there is a relationship of the given parameters.

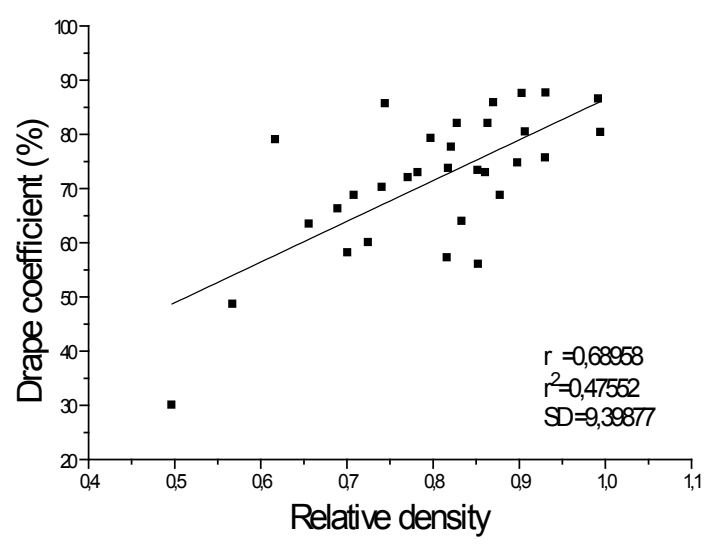

Figure 4. Dependance of drape coefficient and relative density of yarns in fabric

The dependency is set by correlating the drape coefficient and a relative density of the fabric (Fig. 4):

$$
\begin{aligned}
& D C=\sqrt{0,1 \cdot d_{w a} \cdot d_{w e} \cdot\left[\frac{a_{w e}\left(2,6-0,6 z_{w e}\right)}{f_{w e} R_{w a}}\left(\sqrt{v_{w a}{ }^{2}+2 v_{w a} v_{w e}}-v_{w a}\right)+v_{w a}\right]} . \\
& \sqrt{\left[\frac{a_{w a}\left(2,6-0,6 z_{w a}\right)}{f_{w a} R_{w e}}\left(\sqrt{v_{w e}{ }^{2}+2 v_{w a} v_{w e}}-v_{w e}\right)+v_{w e}\right]}[\%]
\end{aligned}
$$

With the analysis of the parameters that define the relative density of the yarns and teh woven fabric drape coefficient the links that will be used for proper projecting of the fabric according to the future purpose can be found.

\section{Conclusion}

Based on these results, it can be concluded that for 
cotton fabrics the drape ability depends on the structure parameters of the fabric. The parameters of the fabric structure can be used to determine the ability of the fabric drape and hence to predict the appearance of the finished garment. Previous studies in this direction were based on mechanical properties of fabrics by which virtual models of garments were obtained. The results show a correct correlation between the drape coefficient, the number of folds and the maximum and minimum amplitude. In addition, a good correlation between the drape coefficient, relative density and fabric weight was found, which establishes a requirement for the development of new methods of projecting drape parameters depending on the structure and construction of the woven fabric for garment industry.

\section{References}

[1] Cusick G. E., A study of Fabric Drape, Faculty of Technology, University of Manchester, 1962, pp: 4-13.

[2] Lojen D. Ž, Jevšnik S., "Some Aspects of Fabric Drape", FIBRES \& TEXTILES in Eastern Europe, Vol. 15, No. 4 (63), pp: 39-45.

[3] Seram N., Rupasinghe W.,"The influence of bending rigidity on drape coefficient of selected lightweight woven fabrics with seams", International Journal of General Engineering and Technology, Vol. 2(1), pp: 25-32

[4] Nofitoska M., Demboski G., Carvalho M. A. F., "Effect of fabric structure variation on garment aesthetic properties",
Tekstil ve Konfeksiyon, Vol: 22(2), pp: 132-136.

[5] Kenkare N. May-Plumlee T., "Evaluation of drape characteristics in fabrics", International Journal of Clothing Science and Technology, Vol. 17 (2), pp: 109-123

[6] Kenkare N., May-Plumlee T., „Fabric Drape Measurement: A Modified Method Using Digital Image Processing", Journal of Textile and Apparel, Technology and Menagement, Vol. 4(3), pp: 1-8

[7] Stepanović J., Ćirković N., Radivojević D., Reljić M., "Defining the warp length required for weaving process", Industria textila, Vol 63 (5), pp: 227-231.

[8] Stepanovic J., Milutinovic Z., Petrovic V., Pavlovic M., " Influence of relative density on deformation characteristics of fabrics in plain weave", Indian Journal of Fibre \& Textile Research, Vol 34 (1), pp. 76-81.

[9] Robson D., Long C. C., „Drape Analysis using Imaging Techniques", Clothing and Textiles Research Journal, Vol 18 (1), pp: 1-8

[10] Frydrych I., Dziworska G., Cieslinska A., „Mechanical fabric properties influencing the drape and handle", Internacional Journal of Clothing, Science and Technology, vol 12 (3), pp 171-183.

[11] Jinlian H.U., "Structure and mechanics of woven fabrics", Woodhead Publishing Limited in association with The Textile Institute, 2004, North America.

[12] Saville B. P., "Physical testing of textiles", Woodhead Publishing Limited in association with The Textile Institute, Abington Hall, Abington, 2000.

[13] Gider, A, "An online fabric database to link fabric drape and end-use properties, Thesis, B.S., Istanbul Technical University, 1997

\section{Izvod}

\section{ANALIZA POVEZANOSTI DRAPIRANJA I STRUKTURE PAMUČNIH TKANINA}

Tatjana Šarac ${ }^{1}$, Jovan Stepanović ${ }^{1}$, Goran Demboski², Vasilije Petrović ${ }^{3}$

(ORIGINALNI NAUČNI RAD)

UDK 684.75

${ }^{1}$ Tehnološki fakultet, Leskovac, Univerzitet u Nišu, Srbija

${ }^{2}$ Tehnološko-metalurški fakultet, Skopje, Univerzitet u Skopju, Republika Makedonija

${ }^{3}$ Tehnički fakultet, Zrenjanin, Univerzitet u Novom Sadu, Srbija

Drapiranje se može opisati kao fenomen formiranja nabora kada je tkanina opterećena sopstvenom masom, bez uticaja spoljašnjih sila. Sposobnost drapiranja materijala ima direktan uticaj na izgled i funkcionalnost odevnog predmeta. Aktuelna saznanja ukazuju da su istraživai uglavnom objašnjavali fenomen drapiranja na osnovu mehanikih svojstava tekstilnih materijala. U radu je prikazana metoda koja ima za cilj da se parametri drapiranja unapred predvide, pri čemu je drapiranje definisano u zavisnosti od parametara strukture i konstrukcije tkanih materijala. Posebna pažnja usmerena je na povezivanju koeficijenta drapiranja sa površinskom masom i relativnom gustinom tkanine. Relativna gustina je definisana parametrima strukture i konstrukcije tkanine kao što su podužna masa pređe, zapreminska masa vlakana, koeficijent pakovanja vlakana u pređi, raport prepletaja, broj promena efekata žica u raportu, položaj vezivnih tačaka u raportu prepletaja i koeficijent fleksibilnosti primenjenih pređa.
Ključne riječi: drapiranje, relativna gustina, tkanina, pamuk 